\title{
Modified gradient method in a decision support system for control unmanned aerial vehicles
}

\author{
O. V. Barabash, N. B. Dakhno, H. V. Shevchenko \\ State University of Telecommunications, Kyiv, Ukraine
}

Paper received 09.12.17; Revised 13.12.17; Accepted for publication 15.12.17.

https://doi.org/10.31174/SEND-NT2017-148V16-16

\begin{abstract}
We consider dynamic models of decision support systems for controlling unmanned aircraft set of equations with small nonlinearity and the $K$ - positive determined $K$-symmetric operators. To these models, gradient method is applied. Methodology is developed for practical convenience of gradient methods. Application of gradient methods to dynamic models in decision support systems for controlling unmanned aircraft consists of algorithms and corresponding unit circuits. Present method makes it possible to optimally implement of gradient methods in the automation control drones.
\end{abstract}

Keywords: dynamic models, decision support system, flight mission, unmanned aerial vehicles, gradient method.

Introduction. Mathematical courses of universities, focus on the substantiation of the mathematical apparatus and the formal methods of solving a narrow class of problems. As a result, the course of mathematics is unjustifiably complicated, overloaded with non-working material and at the same time poor in content. It does not take into account modern trends in applied mathematics, in particular, related to the development of methods that have a broad and relevant application area of application, with considerable attention to algorithms and computers. Teachers of mathematics at universities while refining the course often do not care about how the student will "work" in the future. Therefore moving from the course of mathematics to other disciplines in order to study special literature, and later - to practical activities, he forced to radically retrain.

The course of mathematics for military specialists now has to take into account the current intensive development of the concepts and methods underlying the application of mathematics. It should be a course of applied mathematics, which includes the necessary theoretical concepts.

In practice, a university graduates are often faced with complex computational problems arising from the physical and technical problems. Such tasks can be broken down into a number of elementary ones - such as calculating an integral, solving a differential equation, etc. Many of the basic tasks are simple and well studied. For such tasks, methods of numerical solution have already been developed. There are also quite complex elementary tasks

These methods include methods of variational-gradient type which arose from a combination of ideas of direct and iterative methods. Such synthesis is due to the need to eliminate the inherent weaknesses.

The theory of variational-gradient methods is well designed for linear equations in Hilbert space with positive definite symmetric operators $[1,2]$. For equations that do not have such properties, the theory of variational-gradient method is under development. Variational-gradient methods are stable, have a reasonable rate of convergence and does not require knowledge of the functional operator spectrum boundaries.

As a result the spread of these methods to a wider class of equations and the application of the theory of variationgradient methods to dynamic models in the DMSS for remote control of the UAV will increase the accuracy and speed of the calculations during the flight in accordance with the given program. This will allow to develop or adjust the optimal UAV flight program for solving the problems of observation and search of specified objects in real time,

\section{Main part}

1. The problem setting. In order to minimize the cost of performing the flight tasks, it is necessary to implement an appropriate decision support system (DSS), which allows real time development of the optimal UAV flight program [3].

The decision support system includes a number of mathematical models. The main part consists of models based on the integral-differential equations, often nonlinear.

To date, research on nonlinear UAV models has been developed very poorly. Therefore, the propagation of the gradient method to a class of equations with small nonlinearity and K-positively defined K-symmetric operator is an actual and important task.

2. The analysis of the last studies and publications. The task of planning the trajectory in the context of managing complex technical objects is studied from the 50s of the XX century. One of the first projects in this area was the wellknown project by Stanford University of the United States for the creation of the SHAKEY robot in 1966-1972. It was the project which initiated a long-term study of methods and approaches for solving trajectory planning and the management of unmanned aerial vehicles, which are paid a lot of attention $[4,5]$.

Recently, considerable attention has been paid to the application of decision support systems for control tasks and the safety level of UAV flight [1, 6-8]. Unfortunately, almost all existing trajectory planning methods used in modern aircraft unmanned aerial vehicle control systems are resource-intensive.

3. The algorithm of modified gradient method. The basis of the systems for monitoring the surface by the UAV is a decision support system that is described by mathematical models. The algorithms that coordinate the dynamic characteristics of the observation object with the flight parameters of the UAVs are explored and developed in such systems.

An acceleration of the decision of mathematical models with weak nonlinearity with the help of modified gradient method will allow to improve the accuracy of UAV control and increase the reliability of the adopted decisions.

We shall consider a dynamic model, which is described by the following equation:

$$
A u+\lambda F=f, f \in H,
$$

here $\lambda-$ is a parameter, $\mathrm{H}-$ Hilbert space, operator $\mathrm{A}: \mathrm{D}(\mathrm{A}) \rightarrow \mathrm{H}$ is defined on a dense in $\mathrm{H}$ set is a linear $\mathrm{K}$ positive definite and K-symmetric [9]. That is, there is a closing operator $\mathrm{K}: \mathrm{D}(\mathrm{K}) \rightarrow \mathrm{H}, \mathrm{D}(\mathrm{K}) \subset \mathrm{D}(\mathrm{A})$, such as $\exists \mu, v>0:(A u, K u) \geq \mu\|u\| 2, \forall u \in D(A)$, 


$$
\begin{aligned}
\|K u\| 2 & \leq v(A u, K u), \forall u \in D(A), \\
(A u, K v) & =(A v, K u), \forall u, v \in D(A),
\end{aligned}
$$

Assume that there exists a linear K-positive definite and K-symmetric operator, $\mathrm{B}: \mathrm{D}(\mathrm{B}) \rightarrow \mathrm{H}$ i $\mathrm{D}(\mathrm{B})=\mathrm{D}(\mathrm{A})$, for which it is easy to construct an inverse one.

Let the condition be fulfilled:

$$
\exists \gamma, \delta>0: 0<\gamma<\delta<\infty,
$$

$$
\forall u \in D(A) \gamma(B u, K u) \leq(A u, K u) \leq \delta(B u, K u)
$$

Operator $\mathrm{F}: \mathrm{D}(\mathrm{F}) \rightarrow \mathrm{H}$ defined on a set that is dense in $\mathrm{H}$ and $\mathrm{D}(\mathrm{A}) \subset \mathrm{D}(\mathrm{F})$ is nonlinear $K$ - monotonous $\mathrm{K}$-Lipschitz continuous that is:

$$
\begin{gathered}
\exists \alpha, \beta>0: \forall u, v, h \in D(F) \\
\|(F u-F v, K(u-v))\| \geq \alpha(B(u-v), K(u-v)) \\
\|(F u-F v, K(u-v))\| \leq \beta(B(u-v), K(u-v))
\end{gathered}
$$

Under (2) - (7) equation (1) has a single generalized solution.

We consider the equation (1) and assume that (2) - (7) are fulfilled.

Let $\mathrm{u}_{0} \in \mathrm{D}(\mathrm{A})$ - arbitrary initial approximation. Suppose that $(\mathrm{k}-1)$-th approximation is found. Then for the following ones we use the scheme:

$$
B u_{k}=B u_{k-1}+\tau_{k} r_{k},
$$

here $\tau_{\mathrm{k}}$ the coefficient, a $\mathrm{r}_{\mathrm{k}}-$ mismatch

$$
r_{k}=f-A u_{k-1}-\lambda F u_{k-1}
$$

Unknown coefficient $\tau_{\mathrm{k}}$ we can find from the functional minimum condition

$$
\Phi\left(u_{k}\right)=\left(A u_{k}, K u_{k}\right)-2\left(f, K u_{k}\right)+2 \lambda\left(F u_{k-1}, K u_{k}\right)
$$

As there are exists an reversed operator for B, then (8) can be rewritten in a form

$$
u_{k}=u_{k-1}+\tau_{k} B^{-1} r_{k}
$$

From the condition of the minimum of the functional (10), taking into account (11) we obtain the formula for $\tau_{\mathrm{k}}$ determination:(

$$
\tau_{k}=\frac{\left(B^{-1} r_{k}, K r_{k}\right)}{\left(A B^{-1} r_{k}, K B^{-1} r_{k}\right)}
$$

4. Validation of modified gradient method. Let's set a new scalar product on $D(B)$ : $[u, v]=(B u, K v), u, v \in D(B)$.

Then, for (13), all axioms of the scalar product hold, and the linear set $D(B)$ can be considered as a real Hilbert space. We will call the closure of a set $D(B)$ in the sense of the metric (13) an energy space $\mathrm{H}_{\mathrm{B}}$. The norm of an element $u$ in space $\mathrm{H}_{\mathrm{B}}$. will be denoted $|u|_{B}$, so that

$$
\|u\|_{B}^{2}=[u, u], u \in D(B) \text {. }
$$

Theorem. If in (1) the operators $A$ and $F$ satisfy the conditions (2) - (7), parameter $|\lambda|<\frac{2 \gamma^{\frac{2}{5}}}{\beta \sqrt{\delta}(\gamma+\delta)}$, then the modified gradient method $(8)-(12)$ is convergent and the rate of convergence is characterized by:

$$
\begin{gathered}
\left\|u^{*}-u_{k}\right\|_{B} \leq \eta q^{k}\left\|u^{*}-u_{0}\right\|, k \geq 1, \\
\eta=\frac{\delta+\lambda \beta}{\gamma+\lambda \alpha}, q=\rho+|\lambda|+\frac{\beta \sqrt{\delta}}{\gamma^{3 / 2}}, \rho=\frac{\delta-\gamma}{\delta+\gamma} .
\end{gathered}
$$

Proof: Let $K_{0}$ - be the expansion of the operator $K$ over space $H_{B}$.. Then operators $A$ and $B$ can be expanded to closed $K_{0}$-positive-definite operators $A_{0}$ and $B_{0}$, such that $A_{0} \supset A$, $B_{0} \supset B, . A_{0} \mathrm{i} \mathrm{B}_{0}$ has continuous inverse ones and $H_{B}$ contains all the elements that implement a minimum of functional $\Phi\left(u_{k}\right)$.

Let:

$$
G=B_{0}^{-1} A_{0}, C=B_{0}^{-1} F, g=B_{0}^{-1} f .
$$

The operator $G$ can be extended all over $H_{B}$. Let's denote this expansion by $G_{0}$.

Let's consider an equation

$$
G_{0} u+\lambda C u=g, g \in H_{B} .
$$

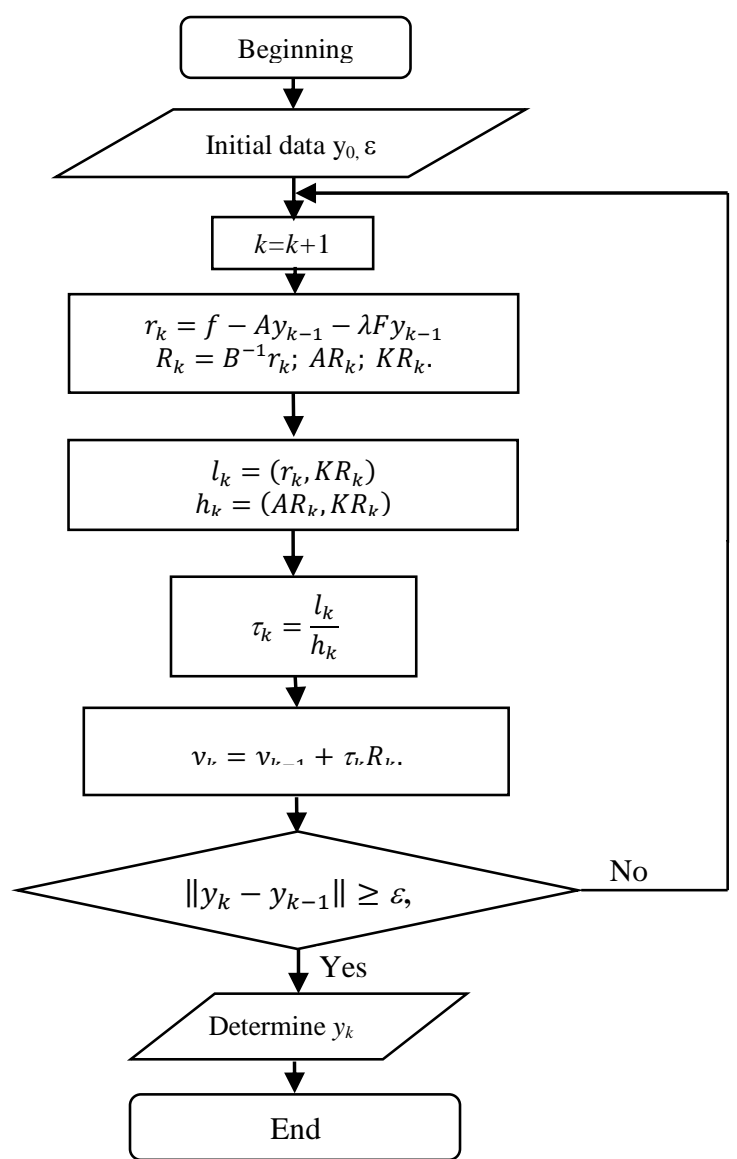

Fig. 1. Block diagram of the modified gradient algorithm a method for equations with small nonlinearity and $K$-positive definite $K$ symmetric operator

The operators $G_{0}$ i $C$ act in space $H_{B}$. Operator $G_{0}$ is a linear positive definite bounded and symmetric in $H_{B}$..So, according to (4) and (17), we get

$$
\begin{gathered}
\forall u, v \in H_{B}:\left[G_{0} u, v\right]=\left[B_{0}^{-1} A_{0} u, v\right]=\left(A_{0} u, K v\right) \\
=\left(A_{0} v, K u\right)=\left[G_{0} v, u\right]
\end{gathered}
$$

And condition (5) is as follows: $\gamma\|u\|_{B}^{2} \leq\left[G_{0} u, u\right] \leq \delta\|u\|_{B}^{2}, \forall u \in H_{B}$.

For a nonlinear operator $C$, conditions (6), (7) will be:

$$
[C u-C v, u-v] \geq \alpha\|u-v\|_{B}^{2}, \forall u, v \in H_{B},
$$$$
[C u-C v, u-v] \leq \beta\|u-v\|_{B}^{2}, \forall u, v \in H_{B} .
$$

According to the inequalities (21), (22), the nonlinear operator $C$ is Lipschitz - continuous and monotonic. That is, equation (18) has a unique solution.

After the replacement (17) method (8) - (12) will look like:

$$
u_{k}=u_{k-1}+\tau_{k} \varepsilon_{k}
$$

where $\varepsilon_{k}=g-G_{0} u_{k-1}-\lambda C u_{k-1}$, and unknown coefficient $\tau_{k}$ is found from the condition of functional minimum:

$$
\widetilde{\Phi}\left(u_{k}\right)=\left[G_{0} u_{k}, u_{k}\right]-2\left[g, u_{k}\right]+2 \lambda\left[C u_{k-1}, u_{k}\right] .
$$

After transformations we get an expression to define $\tau_{k}$

$$
\tau_{k}=\frac{\left[\varepsilon_{k}, \varepsilon_{k}\right]}{\left[G_{0} \varepsilon_{k}, \varepsilon_{k}\right]}
$$

Thus, the solution of equation (1) by the method (8) (12) is equivalent to solving the equation (18) by the method (23) - (25). According to the convergence theorem of the gradient method applied to equations with small nonlinearity [10], the method (23) - (25) converges, that is, the method (23) - (25) converges too and the rate of convergence is characterized by an estimate (15).

5. Method of application of modified gradient method for dss models with small nonlinearity and $k$-positively defined, $k$-symmetric operator. Consider the computational 
scheme which should be used in practical implementation of the modified gradient method for dynamic models with low nonlinearity and $K$-positively defined $K$-symmetric operator (Fig. 1).

Let $y_{0} \in D(A)$ - be arbitrary initial approximation, $\varepsilon>0$ the required accuracy of the desired solution, $k$ is the iteration number.

1. Initialization of initial data $y_{0}, \varepsilon, k=1$.

2. Calculation of expressions

$r_{k}=f-A y_{k-1}-\lambda F y_{k-1}$;

$R_{k}=B^{-1} r_{k} ; A R_{k} ; K R_{k}$.

3. Calculation of scalar products: $l_{k}=\left(r_{k}, K R_{k}\right), h_{k}=$ $\left(A R_{k}, K R_{k}\right)$

4. Calculation of parameter: $\tau_{k}: \tau_{k}=\frac{l_{k}}{h_{k}}$
5. Calculation of approximation: $y_{k}=y_{k-1}+\tau_{k} R_{k}$.

6. Test of the condition: if $\left\|y_{k}-y_{k-1}\right\| \geq \varepsilon$, then $k=k+$ 1 and repeat $2-6$.

The block diagram for this algorithm is shown in Fig. 1

Conclusion. The application of the modified gradient method to dynamic models described by equations with small nonlinearity and $K$-positively defined $K$-symmetric operators will increase the efficiency of the use of unmanned intelligence and surveillance systems by automating the preparation of the flight task, optimizing the flight path with anchoring to the electronic maps of the area and the definition of optimal flight parameters with the possibility of correction of flight task parameters in real time.

\section{ЛИТЕРАТУРА}

[1] Барабаш О.В., Дахно Н.Б. Методика застосування варіаційноградієнтних методів для динамічних моделей в системах підтримки прийняття рішень. Науково-виробничий збірник «Наукові записки Українського науково-дослідного інституту зв'язку». - Київ : УНДІЗ, 2015, № 5(39), С. 87-92.

[2] Дахно Н. Б. Двокроковий варіаційно-градієнтний метод для рівнянь з К-позитивно визначеним та К-симетричним оператором . Доповіді НАН України. Київ : НАНУ, 2000, № 4, C.14-17.

[3] Самков О.В., Сілков В.І., Гожий О.П., Мавренков О.С. Підтримка прийняття рішень в системі управління літального апарата. Збірник наукових пращь Державного науководослідного інституту авіащії. Київ : ДНДІА, 2012, Вип.(8)15, C.104-109.

[4] Ильюшко В.М., Митрахович М.М., Самков А.В., Силков В.И. Беспилотные летательные аппараты: Методики приближенных расчетов основных параметров и характеристик. Под общ. ред. В.И Силкова. - Київ: ЦНДІ ОВТ ЗС України, 2012, $302 \mathrm{c}$.

[5] Мосов С.П., Хращевський Р.В. Аналіз застосування авіації в післявоєнний період. Системи озброєння $і$ військова техніка. -Харків: ХУПС, 2009, № 1 (17), С.67-71.

[6] Барабаш О.В., Обідін Д.М., Мусієнко А.П. Модель баз знань інтелектуальної системи управління високошвидкісного рухомого об'єкта на основі її верифікації. Системи обробки інформації: збірник наукових працьь. - Харків: ХУПС, 2004, № 5 (121), C.3-6.

[7] Kravchenko Yг., Vialkova V. "The problem of providing functional stability properties of information security systems" Proceedings of the XIIIth International Conference "Modern problems of radio engineering, telecommunications, and computer science» (TCSET'2016) Lviv-Slavsko, Ukraine February 23-26, 2016, pp. 526-530.

[8] Mukhin HU, V., Kornaga Y., Barabash O., Herasymenko O. Analytical Assessment of Security Level of Distributed and Scalable Computer Systems. International Journal of Intelligent Systems and Applications. Vol. 8, № 12, Hong Kong: MECS Publisher, 2016, pp. 57-64.

[9] Petryshyn W. V. On Clas of K-p.d. and Non-K-p.d. Operators and Operator Equation, Journal of Matheamatical analysis and applications. Vol.10, No 1, February, 1965, pp.1-24.

[10] Дахно Н. Б. Застосування модифікованого градієнтного методу до операторних рівнянь 3 малою нелінійністю для аналізу захищеності інформаційних структур. Вісник ДУІКТ. Київ : ДУІКТ, 2009, Том 7(4), С.323-327.

\section{REFERENCES}

[1] Barabash O.V., Dakhno N.B. The technique for implementation of variational-gradient method for dynamic models in decision support system. Scientific and production digest "Scientific proceeing of Ukrainian research institute of communication" , 2015, № 5(39), P. 87-92.

[2] Dakhno N.B. Two-step variational-gradient method for equations with K-positive definite and K-symmetric operator. Reports of the National Academy of Sciences of Ukraine. 2000, № 4, P.14-17.

[3] Samkov O.V., SIlkov V.I., Gozhiy O.P., Mavrenkov O.E. Support for decision making in the aircraft control system. Collection of scientific papers of the State Research Institute of Aviation. 2012, №(8)15, P.104-109.

[4] Ilyushko V.M., Mitrahovich M.M., Samkov A.V., Silkov V.I. Unmanned aerial vehicles: Approximate calculation methods of basic parameters and characteristics. 2012, 302 p.

[5] Mosov S.P., Khrashchevskyi R.V. The analysis of application of aircraft in a post-war period. Weapon systems and military equipment. 2009, № 1 (17), P.67-71.

[6] Barabash O.V., Obidin D.M., Musienko A.P. Knowledge base model of intellectual control system of high-speed moving objects

based on its verification. Information processing system. 2004, № 5 (121), P.3-6.

[7] Kravchenko Yu., Vialkova V. "The problem of providing functional stability properties of information security systems" Proceedings of the XIIIth International Conference «Modern problems of radio engineering, telecommunications, and computer science» (TCSET'2016) Lviv-Slavsko, Ukraine February 23-26, 2016, pp. 526-530.

[8] Mukhin HU, V., Kornaga Y., Barabash O., Herasymenko O. Analytical Assessment of Security Level of Distributed and Scalable Computer Systems. International Journal of Intelligent Systems and Applications. Vol. 8, № 12, Hong Kong: MECS Publisher, 2016, pp. 57-64.

[9] Petryshyn W. V. On Clas of K-p.d. and Non-K-p.d. Operators and Operator Equation, Journal of Matheamatical analysis and applications. Vol.10, No 1, February, 1965, pp.1-24.

[10] Dakhno N.B. Application of a modified gradient method to operator equations with a small nonlinearity for the analysis of the security of information structures. Bulletin GUICT. 2009, №7(4), P.323-327.

\footnotetext{
Модифицированный градиентных методов в системах поддержки принятия решений для управления беспилотных летательных аппаратов

О. В. Барабаш, Н. Б. Дахно, Г. В. Шевченко

Аннотация: Рассмотрены динамические модели систем поддержки принятия решений для управления беспилотными летательными аппаратами заданными уравнениями с малым нелинейностью и К-положительнными определенными К-симметричными операторами. Приведеная методика применения модифицированного градиентного метода, которая дает возможность оптимально реализовывать метод в процессе автоматизации управления беспилотными летательными аппаратами.

Ключевые слова: динамические модели, система поддержки принятия решений, беспилотный летательный аппарат, траектория полета, вариачионно-градиентный метод, градиентный метод.
} 